\title{
Determinants of Opportunistic Infections Among HIV-Positive Patients on HAART in Debre Berhan Referral Hospital, North Shoa Zone, Ethiopia, 2020: A Case-Control Study
}

This article was published in the following Dove Press journal:

HIVIAIDS - Research and Palliative Care

\author{
Abrham Shitaw Tewachew iD ' \\ Wassie Negash Mekonnen ${ }^{2}$ \\ Abinet Dagnaw Mekuria (iD ${ }^{2}$ \\ Yosef Eshetie Amare (iD ${ }^{3}$ \\ 'Department of Medicine, Institute of \\ Medicine and Health Sciences, Debre \\ Berhan University, Debre Berhan, \\ Ethiopia; ${ }^{2}$ Department of Public Health, \\ Institute of Medicine and Health Sciences, \\ Debre Berhan University, Debre Berhan, \\ Ethiopia; ${ }^{3}$ Department of Biomedical \\ Sciences, Institute of Medicine and Health \\ Sciences, Debre Berhan University, \\ Debre Berhan, Ethiopia
}

Introduction: Opportunistic infections are an illness that exists more frequently and is more severe in people with HIV. In HIV/AIDS patients, opportunistic infections still cause morbidity and mortality even after the era of highly active antiretroviral therapy (HAART) and most patients die as direct or indirect complications of opportunistic infections. This study was aimed to identify the determinants for the occurrence of opportunistic infections in HIV-positive patients having HAART follow-up in DBRH, Debre Berhan, Ethiopia.

Methods: A total of 339 study subjects were involved under institution-based unmatched case-control study design and simple random sampling technique. A pre-tested structured questionnaire was used for data collection. Data were entered using Epidata version 3.1 and analyzed for descriptive and logistic regression models by SPSS version 21. A $P$-value of less than 0.05 was considered as statistically significant.

Results: After adjusting potential confounders, drinking alcohol ( $\mathrm{AOR}=3.12,95 \% \mathrm{CI}$ : 1.07-9.06), BMI <18.5 (AOR=3.36, 95\% CI: 1.49-7.55), previous history of opportunistic infections $(\mathrm{AOR}=2.96,95 \% \mathrm{CI}: 1.51-5.8)$ were independent predictors of opportunistic infections in people living with HIV/AIDS on HAART.

Conclusion: In this study, the poor clinical and biochemical status, and behavioral factors were being the predictors of the occurrence of opportunistic infections. HIV/AIDS patients must be assessed and screened for opportunistic infections.

Keywords: opportunistic infections, HIV/AIDS, HAART, CD4, Debre Berhan, Ethiopia

\section{Introduction}

Human Immunodeficiency Virus (HIV) related opportunistic infections (OIs) have been defined as infections that are more frequent or more severe because of HIVmediated immunosuppression. ${ }^{1-5}$

HIV infection and OIs have bi-directional relationships. ${ }^{6-10}$ Having HIV weakens the immune system and causes the risk of developing opportunistic infections. On the other hand, OIs can affect the natural history of HIV/AIDS infection by causing reversibly boosting viral load that speed up HIV progression and increases its transmission. ${ }^{2,3,11-13}$

OIs are the leading causes of morbidity and mortality among HIV-infected individuals. ${ }^{3}$ It affects different body parts such as mainly the nervous, gastrointestinal, respiratory systems, and the skin. The occurrence and type of opportunistic infections depend on the level of immunity. For example, in the early stage, milder
Correspondence: Yosef Eshetie Amare Department of Biomedical Sciences, Institute of Medicine and Health Sciences Debre Berhan University, Debre Berhan, Ethiopia

Tel +251910966364

Email yophy2006@gmail.com 
infections such as herpes zoster and skin infections would occur. However, lethal infections such as central nervous system toxoplasmosis (CNS toxoplasmosis) and cryptococcal meningitis exist later with severe immunesuppression. Pneumonia and tuberculosis (TB) might occur in either early or later stages of HIV/AIDS infection. $^{12,14-16}$

Ethiopia is a country with a large percentage of HIVinfected population with a total of 737,186 population living with HIV where the occurrence of opportunistic infection is considered as minor infections until they present with life-threatening complications. ${ }^{5}$

Most of the states in Ethiopia have an HIV prevalence of $1 \%$ and more. For example, Gambella, Addis Ababa, Dire Dawa, and Harari have an HIV prevalence of $4.8 \%$, $3.4 \%, 2.5 \%, 2.4 \%$, respectively. ${ }^{11}$

In developing countries including Ethiopia, immediate determinants for opportunistic infections on HAART receiving patients are not studied well; though several studies on the prevalence and associated factors of OIs were investigated in the general population. The occurrence of opportunistic infections in HIV patients who started treatment with HAART and its determinant factors are not fully understood and opportunistic infections remain the main causes of morbidity, mortality, and deterioration of clinical conditions in patients with HIV. Therefore, it is quite essential to see the determinants of opportunistic infections to minimize potential challenges. Health planners, researchers as well as clinicians will also get important insights from this work.

\section{Methods}

\section{Study Area}

The study was conducted in Debre Berhan Referral Hospital (DBRH) which is located 130kilometers north of Addis Ababa. It was established in 1929 E.C. It is giving curative health care services for more than 2.8 million people (from North Shewa, Oromia, and neighboring Afar regions). The Hospital gives emergency, inpatient, outpatient, delivery, and specialized services. The antiretroviral therapy (ART) clinic is one of the departments in the outpatient case team of the hospital.

The ART clinic has its separate outpatient department (OPD) room, follow-up room, adherence counseling room, and a separate waiting area. The clinic gives follow-up service for diagnosed HIV patients. It also gives clinical care for HIV-exposed children and enrolled them in the follow-up if HIV is confirmed after clinical and laboratory evaluation.
The clinic has one physician, four clinical nurses trained on treatment and follow-up of patients with HIV, four adherence counselors, two data clerks, and two pharmacists. It also has job aids (for drug dosing, for diagnosing and handling of drug side effects), updated national treatment guidelines, registration books, reporting formats, and inter and intra-facility patient transferring slips. Two thousand one hundred and forty-eight clients had followups in the unit in the 2018/19 fiscal year.

\section{Study Design and Period}

The hospital-based unmatched case-control study was carried out from February 2020 - March 2020 to see determinant factors of opportunistic infections in HIV-infected patients who received HAART and who have at least one of the disease-defining illnesses for opportunistic infections. HIV infected patients on HAART who does not have any of the disease-defining illness for opportunistic infections were taken as controls.

\section{Source Population}

All HIV-positive patients who are on HAART were the source population of the study.

\section{Study Population}

All HIV-positive patients who follow in the ART followup clinic, and admitted to the wards of DBRH in the study period were taken as the study population.

\section{Inclusion Criteria}

Cases were defined as all HIV/AIDS patients with known opportunistic infection who followed their treatment in the hospital. And, controls were defined as all HIV patients with no opportunistic infection who followed their treatment in the hospital.

\section{Exclusion Criteria}

Critical patients who were not able to respond to the interview.

\section{Determination of Sample Size}

Epi Info ${ }^{\text {TM }}$ statistical program was used to calculate the sample size using unmatched case-control formula. One of the determinants of opportunistic infections (controls exposed $46.1 \%$, an OR of 1.974 ) was taken ${ }^{17}$ with the assumptions of $5 \%$ margin of error, two-sided confidence level $95 \%$, and $80 \%$ power of the test, finally, the total sample size was 339 (113 cases and 226 controls). 


\section{Sampling Technique}

A consecutive sampling method was applied for cases and simple random sampling was used to select controls from patients attending the ART clinic for follow-up and who are admitted to the medical wards.

\section{Study Variables}

The research variables were selected after a thorough literature review was conducted and variables of interest were selected and customized to the study. We measured sociodemographic characteristics such as; age, sex, marital status, educational status, and occupation as independent variables. Also, variables measured in the study were behavioral factors (alcohol use, cigarette smoking, khat chewing, drug adherence). Individual clinical related factors (Baseline CD4 count, prophylaxis for OIs). The occurrence of opportunistic infections was taken as a dependent variable.

\section{Operational Definitions}

Cases: HIV patients on HAART who developed opportunistic infections any time after the start of the treatment and diagnosed at the time of interview such as Herpes Zoster, Bacterial Pneumonia, Pulmonary Tuberculosis, EPTB, Candidiasis, Aphthous Ulcer, PCP, CNS Toxoplasmosis, Cryptococcal meningitis, Chronic diarrhea, Kaposi's Sarcoma, Lymphoma, Cervical cancer.

Control: HIV infected patients on HAART who does not have any of the disease defining illness for opportunistic infections (Herpes Zoster, Bacterial Pneumonia, Pulmonary Tuberculosis, EPTB, Candidiasis, Aphthous Ulcer, PCP, CNS Toxoplasmosis, Cryptococcal meningitis, chronic diarrhea, Kaposi's sarcoma, Lymphoma, Cervical cancer).

Good adherence: $>95 \%(<2$ doses of 30 doses or $<3$ doses of 60 doses missed); Fair adherence: between $85 \%$ and $94 \%$ (3-5 dose of 30 doses or 3-9 dose of 60 doses is missed); Poor adherence: $<85 \%$ ( $\geq 6$ doses out of 30 doses or $>9$ doses out of 60 doses missed) as documented by ART physician.

Working: able to perform usual work in or out of the house; Ambulatory: able to perform activities for daily living; Bedridden: not able to perform activities of daily living.

\section{Data Collection Process}

Data was collected by 4 trained nurses who are working in the ART clinic. Data were collected with a pretested intervieweradministered questionnaire to collect the socio-demographic and behavioral factors. Other data regarding the clinical conditions of patients were collected from the medical registry of the patients and registered in a form that was formulated to collect data.

\section{Data Quality Control}

Every questionnaire was coded for specific patients. The completeness of data was checked in a daily manner by the principal investigator. Double entry was done to ensure the maximum level of completeness. The principal investigator communicated and checked the data collection process, gave feedback and correction to ensure the completeness, accuracy, and clarity of the collected data were checked carefully. Timely corrections were made when there were confusions during the data collection process. Data coding, entering, verifying, and cleaning was performed with due care.

\section{Data Analysis}

Epidata version 3.1 and SPSS version 21 statistical software were employed for data entry and analysis, respectively. Summary values were obtained by computing descriptive statistics. The association of independent and dependent variables was determined using bivariate analysis. A p-value less than 0.05 at a $95 \%$ confidence interval was taken statistically significant difference. Then, variables that had a $p$-value less than 0.2 in the bivariate analysis were further subjected to multivariate logistic regression to identify predictors of developing opportunistic infections using the odds ratio as a measure of associations between variables. Tables and charts were computed using Ms-Excel-2013.

\section{Results \\ Sociodemographic Characteristics of Participants}

Three hundred and thirty-nine study subjects (113 cases and 226 controls) were involved in this research. Of the total 339 study participants, 141 (41.6\%) were male and 198 (58.4\%) were female as presented in Table 1. The median age of the respondents was found to be 40.51 \pm 11.413 with the minimum being 15 years old and the maximum 74 years old.

The majority (81.1\%) of the study participants were urban dwellers while $18.9 \%$ of them are from rural areas. Regarding educational status, $33.6 \%$ completed secondary school while $24.2 \%$ had no formal education. Participants who completed a college diploma and above were $64(18.8 \%)$. Of the study 
Table I Sociodemographic Characteristics of People Living with HIV Who Had a Follow-Up in Debre Berhan Referral Hospital, 2020

\begin{tabular}{|c|c|c|c|c|c|c|c|}
\hline \multicolumn{2}{|l|}{ Variables } & \multicolumn{2}{|c|}{ Cases $(n=I \mid 3)$} & \multicolumn{2}{|c|}{ Controls $(n=226)$} & \multicolumn{2}{|l|}{ Total } \\
\hline & & \multirow{3}{*}{$\begin{array}{l}\text { Freq (n) } \\
41 \\
72\end{array}$} & \multirow{3}{*}{$\begin{array}{l}\text { Percentage (\%) } \\
36.28 \\
63.71\end{array}$} & \multirow{3}{*}{$\begin{array}{l}\text { Freq (n) } \\
100 \\
126\end{array}$} & \multirow{3}{*}{$\begin{array}{l}\text { Percentage (\%) } \\
44.24 \\
55.75\end{array}$} & \multirow{3}{*}{$\begin{array}{l}\text { Freq (n) } \\
14 \mid \\
198\end{array}$} & \multirow{3}{*}{$\begin{array}{l}\text { Percentage (\%) } \\
41.59 \\
58.40\end{array}$} \\
\hline Sex & Male & & & & & & \\
\hline & Female & & & & & & \\
\hline Age & $\leq 18$ & 3 & 2.655 & 6 & 2.65 & 9 & 2.65 \\
\hline & $18-29$ & 19 & 16.81 & 26 & 11.50 & 45 & 13.27 \\
\hline & $30-39$ & 37 & 32.74 & 76 & 33.62 & 113 & 33.33 \\
\hline & $40-60$ & 51 & 45.13 & 105 & 46.46 & 156 & 46.01 \\
\hline & $\geq 60$ & 3 & 2.65 & 13 & 5.75 & 16 & 4.72 \\
\hline \multirow[t]{4}{*}{ Marital Status } & Single & 26 & 23 & 29 & 12.83 & 55 & 16.22 \\
\hline & Married & 40 & 35.39 & 105 & 46.46 & 145 & 42.77 \\
\hline & Divorced & 30 & 26.54 & 62 & 27.43 & 92 & 27.13 \\
\hline & Widowed & 17 & 15.04 & 30 & 13.27 & 47 & 13.86 \\
\hline \multirow[t]{6}{*}{ Occupation } & Unemployed & 32 & 28.31 & 46 & 20.35 & 78 & 23 \\
\hline & Farmer & 11 & 9.73 & 36 & 15.92 & 47 & 13.86 \\
\hline & Private Worker & 22 & 19.46 & 35 & 15.48 & 57 & 16.81 \\
\hline & Government Employee & 21 & 18.58 & 53 & 23.45 & 74 & 21.82 \\
\hline & Daily Laborer & 24 & 21.23 & 52 & 23.00 & 76 & 22.41 \\
\hline & Student & 3 & 2.65 & 4 & 1.77 & 7 & 2.065 \\
\hline \multirow[t]{2}{*}{ Residence } & Urban & 91 & 80.53 & 184 & 81.41 & 275 & 81.12 \\
\hline & Rural & 22 & 19.46 & 42 & 18.58 & 64 & 18.87 \\
\hline \multirow[t]{5}{*}{ Educational status } & No formal education & 30 & 26.54 & 52 & 23 & 82 & 24.18 \\
\hline & Primary & 27 & 23.89 & 52 & 23 & 79 & 23.30 \\
\hline & Secondary & 45 & 39.82 & 69 & 30.53 & 114 & 33.62 \\
\hline & College Diploma & 3 & 2.65 & 28 & 12.38 & 31 & 9.14 \\
\hline & Degree and above & 8 & 7.08 & 25 & 11.06 & 33 & 9.73 \\
\hline
\end{tabular}

participants, $48.7 \%$ live in their own house where $40.1 \%$ live in rented houses while $10.3 \%$ live with relatives and 3 respondents live in the street. Of households, $96.1 \%$ have $<5$ people living in the same house, while the rest $3.9 \%$ have between 6 and 10 people living in the same house. The mean monthly income was $2621.60 \pm 2724.7$ ETB with the minimum being 500 and the maximum 15,000 .

\section{Behavioral Characteristics}

Of the 339 study participants, 53 of them take alcohol while being on HAART whereas 286 participants do not take any alcohol while on Medications. Five respondents smoke a cigarette while 334 respondents were not smokers while being on HAART. Twenty-one respondents chew Khat whereas 318 participants had no use of khat while on medications. From the cases, $91.15 \%$ had no use of khat while on HAART where only $8.85 \%$ had use of Khat while on medications (Table 2).

\section{Clinical Characteristics}

Out of the 339 study participants, 41 had a diagnosed chronic illness. From chronic illnesses, hypertension takes $46.3 \%$ followed by diabetes mellitus which accounts for $19.5 \%$. Lung diseases account for $9.8 \%$, neurologic disorders account for $12.2 \%$ of chronic illnesses while cardiac diseases, renal diseases, and mental disorders account for $4.9 \%, 4.9 \%$, and $2.4 \%$, respectively (Figure 1).

Of the 339 study participants, 123 (36.2\%) of study participants had a previous history of opportunistic infections while the other $63.7 \%$ had no history of opportunistic infections. Of the cases, $59.3 \%$ had a previous history of opportunistic infections while only $24.7 \%$ of controls had a history of opportunistic infections (Figure 2).

Categorizing participants based on the Body Mass Index (BMI), the majority of respondents have a baseline BMI of 18.5-24.9, which is normal weight. About 113 respondents were underweight who have a baseline BMI of less than 18.5 (Figure 3). 
Table 2 Behavioral Factors of People Living with HIV Who Had a Follow-Up in Debre Berhan Referral Hospital, 2020

\begin{tabular}{|c|c|c|c|c|c|c|c|}
\hline \multicolumn{2}{|l|}{ Variables } & \multicolumn{2}{|c|}{ Cases $(n=1 \mid 3)$} & \multicolumn{2}{|c|}{ Controls $(n=226)$} & \multicolumn{2}{|l|}{ Total } \\
\hline & & Freq (n) & Percentage (\%) & Freq (n) & Percentage (\%) & Freq (n) & Percentage (\%) \\
\hline \multirow[t]{2}{*}{ Alcohol intake } & Yes & 28 & 24.78 & 25 & 11.062 & 53 & 15.63 \\
\hline & No & 85 & 75.22 & 201 & 88.938 & 286 & 84.37 \\
\hline \multirow[t]{2}{*}{ Smoking } & Yes & 4 & 3.54 & I & 0.442 & 5 & 1.47 \\
\hline & No & 109 & 96.46 & 225 & 99.558 & 334 & 98.53 \\
\hline \multirow[t]{2}{*}{ Khat Chewing } & Yes & 10 & 8.85 & II & 4.867 & 21 & 6.19 \\
\hline & No & 103 & 91.15 & 215 & 95.133 & 318 & 93.81 \\
\hline
\end{tabular}

Out of the 339 participants, 237 have a recent CD4 count of 350 and above followed by 54 participants who have a CD4 count of 201-349. Thirty-seven participants have a CD4 count of 50-200 while the rest 11 participants have a CD4 count of $<50$ (Figure 4).

Out of 339 study participants, 292 took or completed Isoniazid prophylaxis while the rest $47 \mathrm{did}$ not take tuberculosis prophylaxis. Moreover, 222 participants took Cotrimoxazole prophylaxis and 117 participants did not take Cotrimoxazole prophylaxis (Table 3).

\section{Associated Factors with the Occurrence of Opportunistic Infections}

In the bivariate analysis, marital status, alcohol intake, drug adherence, taking Isoniazid prophylaxis, recent CD4 count, recent hemoglobin status, current body mass index, previous history of opportunistic infections, history of opportunistic infection in the family or household were significantly associated with developing an opportunistic infection (Table 4).
Divorced and widowed participants are 2.13 times higher risk to develop OIs than participants who married to $95 \%$ CI (1.17-3.891). But Age, sex, educational status, and occupation have no association with the development of opportunistic infection.

Study participants who drink alcohol while on HAART medications are 2.64 times more likely to develop opportunistic infections than those who do not drink alcohol with 95\% CI (1.45-4.8). HIV patients who had poor drug adherence are at 10.3 times higher risk of getting an opportunistic infection than those patients with good adherence $95 \%$ CI (3.36-31.9).

Patients who do not take Isoniazid prophylaxis for tuberculosis are 3 times more likely to develop opportunistic infections with $95 \%$ CI (1.55-5.46) than patients who are taking prophylaxis for tuberculosis. Taking Cotrimoxazole prophylaxis has a preventive relation for opportunistic infection with COR 0.7 with $95 \%$ CI (0.44-1.13).

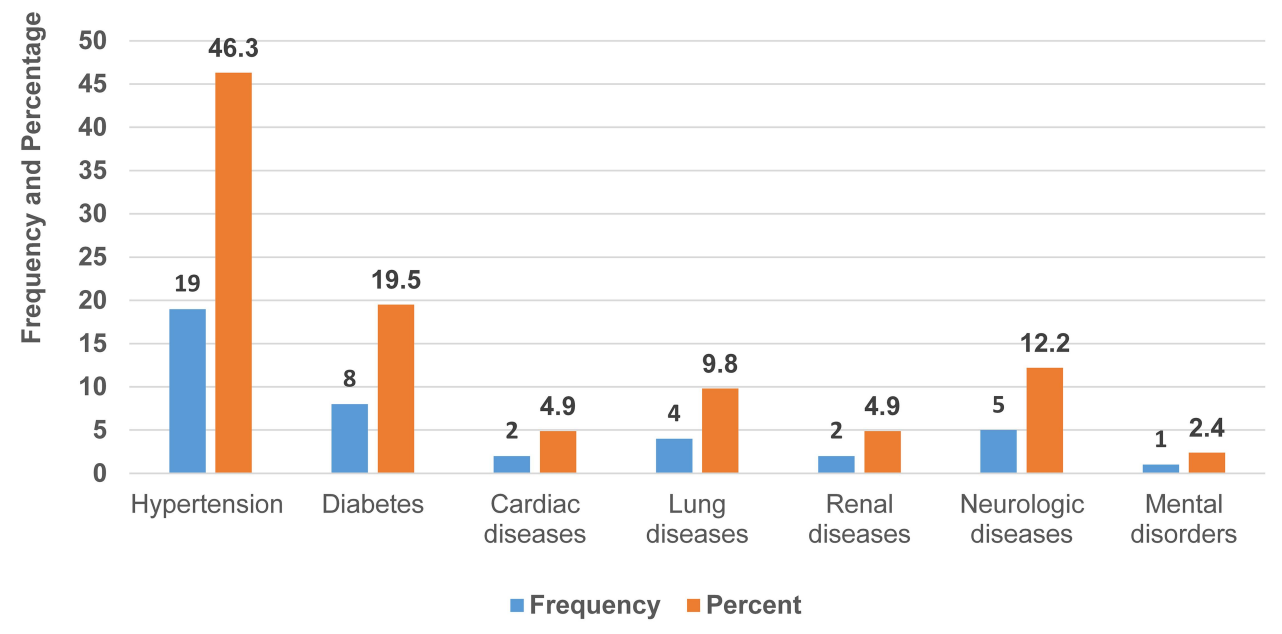

Figure I Summary of chronic illnesses among HIV patients on HAART in Debre Berhan Referral Hospital, 2020. 


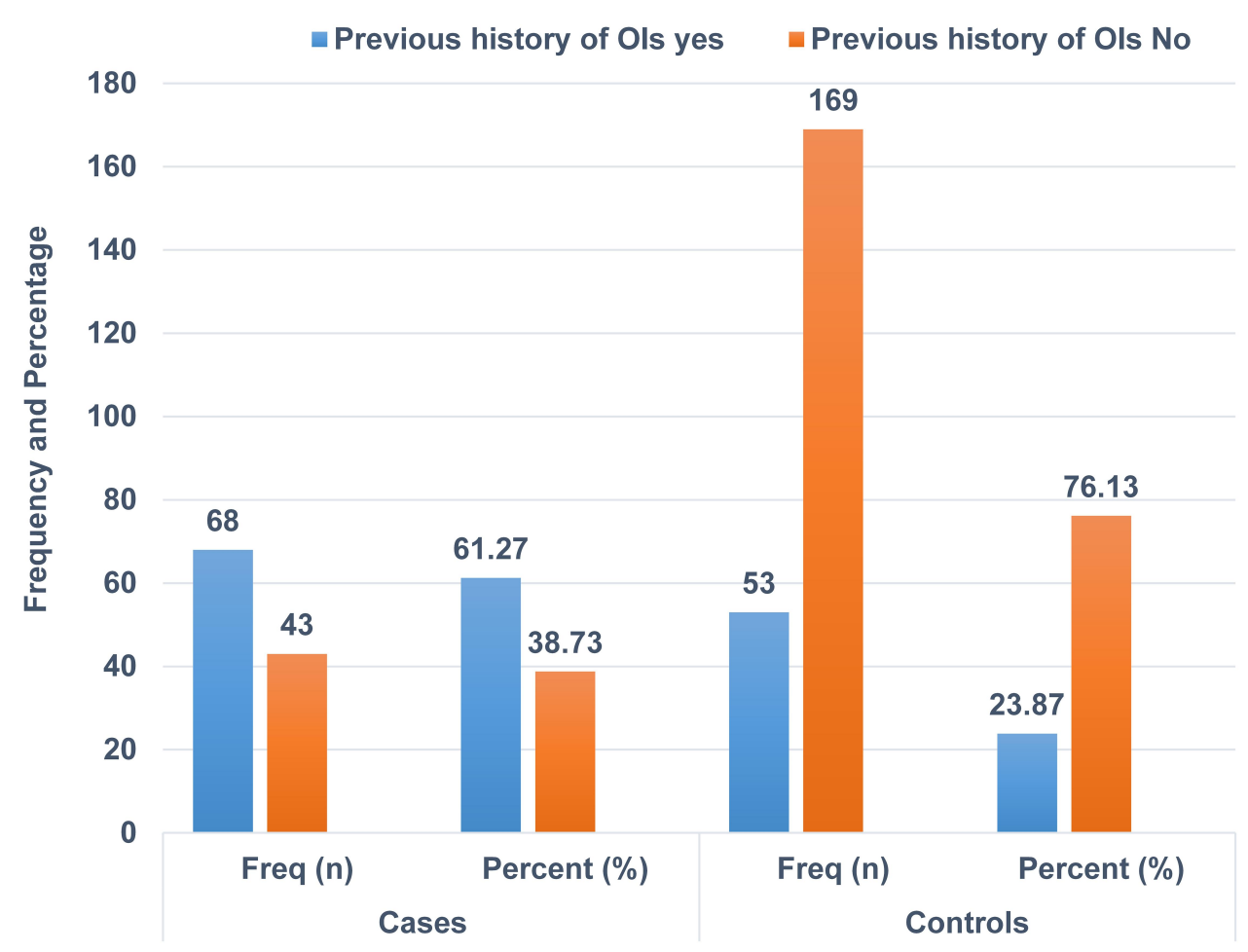

Figure 2 Previous history of opportunistic infections among people living with HIV who had follow-up in Debre Berhan Referral Hospital, 2020.

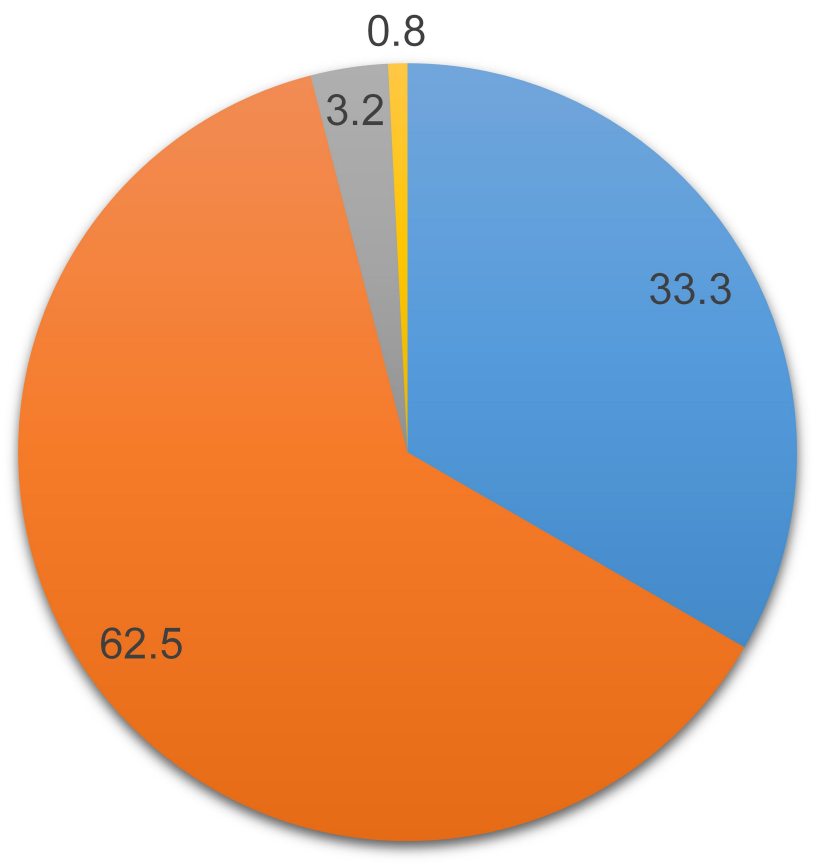

\section{$<18.5 \square 18.5-24.9 \quad \square 25-29.9 \quad \square \geq 30$}

Figure 3 BMI category among HIV patients on HAART in Debre Berhan Referral Hospital, 2020.
Recent CD4 count has a significant association with the occurrence of opportunistic infections with patients who have a recent CD4 count of $<200$ cells $/ \mu \mathrm{L}$ are 6.5 times more likely to develop opportunistic infections $95 \%$ CI (3.32-12.78) than patients who have a recent CD4 count of $\geq 200$ cells $/ \mu \mathrm{L}$. Patients with recent hemoglobin of $<10 \mathrm{mg} / \mathrm{dl}$ are 12 times riskier to develop opportunistic infection compared to patients who have recent hemoglobin of $\geq 10 \mathrm{mg} / \mathrm{dl}$ with 95\% CI (3.49-43). Body mass index has a significant association with opportunistic infection with patients who have a body mass index of $<18.5$ are 6.4 times more likely to develop an opportunistic infection with 95\% CI (3.65-11.14) than patients who have a recent body mass index of $\geq 18.5$.

Patients who had a previous history of opportunistic infections are 4.4 times riskier to develop opportunistic infections with $95 \%$ CI (2.73-7.15) than patients who had no previous opportunistic infections. The odds of developing opportunistic infections is 4 times higher in patients who had an opportunistic infection in the family or household with $95 \%$ CI (1.023-16.9).

The alcohol intake, the body mass index, and the previous history of opportunistic infections were found to be 


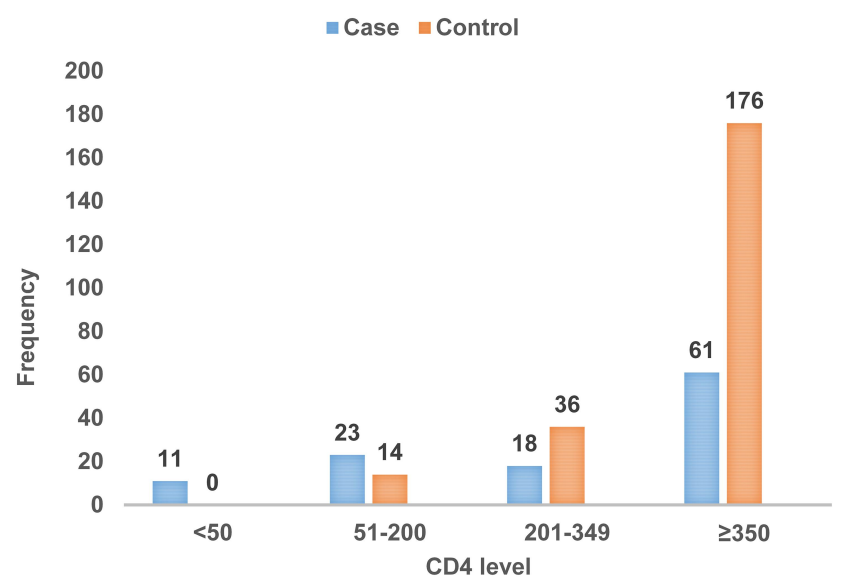

Figure 4 CD4 count of cases and controls in HIV patients on HAART in Debre Berhan Referral Hospital, 2020.

the final independent variables significantly associated with OIs in logistic regression analysis (Table 5).

Patients who drink alcohol were 3.12 times more likely to develop an opportunistic infection than those who do not drink alcohol $(\mathrm{AOR}=3.12,95 \% \mathrm{CI}$ : 1.07-9.06).

Body mass index has a significant association with opportunistic infection with patients who have a body mass index of $<18.5$ are 3.36 times higher risk to develop opportunistic infection $(\mathrm{AOR}=5.7,95 \% \mathrm{CI}$ : 1.49-7.55) than patients who had a recent body mass index of $\geq 18.5$.

The odds of developing opportunistic infections is 3 times higher in patients who had a previous opportunistic infection $(\mathrm{AOR}=2.96,95 \% \mathrm{CI}: 1.51-5.8)$ than patients who had no previous opportunistic infections.

\section{Discussion}

This case-control study has identified several determinant factors for the occurrence of opportunistic infections among HIV-infected people enrolled on HAART in
Debre Berhan referral hospital. The Isoniazid preventive therapy and drinking alcohol while on HAART were found to be independent risk factors for opportunistic infections in this study. The advanced conditions of patients such as being underweight was also associated with the incidence of opportunistic infections.

The study revealed more females are infected with opportunistic infections than their male counterparts. Even though there is no statistically significant association, it is consistent with other studies in Debre Markos, Bahir Dar, Gondar, and Addis Ababa, which founded a more female population infected with opportunistic infections. ${ }^{17-20}$ This may be explained by the higher prevalence of HIV in females than males. It may also be explained by the anatomical characteristics of females which makes them the recipient of genital secretions during sexual intercourse.

This study revealed that educational status has no association with the occurrence of opportunistic infections which are in agreement with studies done in Addis Ababa and Bahir Dar, ${ }^{18,21}$ but inconsistent with other studies that concluded an association between educational status and opportunistic infections. ${ }^{17,19,22}$ This might be explained by larger literate study participants in our study as the mainstream of respondents were from the metropolitan area.

Even though smoking has an established role in the development of opportunistic infections, especially tuberculosis; however, this study has not shown such findings. This could be due to the low prevalence of smoking in our study area. And also, there could be a social desirability bias in which individuals might deny despite they are being smokers.

Drinking alcohol was significantly associated with OIs. Patients who drink alcohol have 3 times more risk of

Table 3 Isoniazid and Cotrimoxazole Prophylaxis Status Among People Living with HIV Who Had a Follow-Up in Debre Berhan Referral Hospital, 2020

\begin{tabular}{|l|l|l|l|l|l|l|l|l|}
\hline \multicolumn{2}{|l}{} & \multicolumn{2}{l|}{ Cases (n= I 13) } & \multicolumn{2}{l|}{ Controls (n=226) } & \multicolumn{2}{l|}{ Total } \\
\cline { 3 - 9 } & & Freq (n) & Percentage (\%) & Freq (n) & Percentage (\%) & Freq (n) & Percentage (\%) \\
\hline \multirow{2}{*}{ Isoniazid Prophylaxis } & Yes & 87 & 76.991 & 205 & 90.71 & 292 & 86.136 \\
& No & 26 & 23.009 & 21 & 9.29 & 47 & 13.864 \\
\hline Cotrimoxazole Prophylaxis & Yes & 68 & 60.177 & 154 & 68.14 & 222 & 66.667 \\
& No & 45 & 39.823 & 72 & 31.86 & 117 & 34.513 \\
\hline Adherence to HAART & Good & 80 & 70.796 & 207 & 91.59 & 287 & 84.661 \\
& Fair & 17 & 15.044 & 15 & 6.64 & 32 & 9.440 \\
& Poor & 16 & 14.159 & 4 & 1.77 & 20 & 5.900 \\
\hline
\end{tabular}


Table 4 Summary of Bivariate Analysis of Associated Factors with Opportunistic Infections in HIV Patients on HAART, Debre Berhan, Ethiopia, 2020

\begin{tabular}{|c|c|c|c|c|c|}
\hline Variable & & Cases & Control & COR $(95 \% \mathrm{Cl})$ & $p$-value \\
\hline Sex & $\begin{array}{l}\text { Male } \\
\text { Female }\end{array}$ & $\begin{array}{l}41 \\
72\end{array}$ & $\begin{array}{l}100 \\
126\end{array}$ & $\begin{array}{l}\text { I } \\
0.72(0.45 I-I . \mid 42)\end{array}$ & 0.161 \\
\hline Age & $\begin{array}{l}\leq 18 \\
18-29 \\
30-39 \\
40-60 \\
>60\end{array}$ & $\begin{array}{l}3 \\
19 \\
37 \\
51 \\
3\end{array}$ & $\begin{array}{l}6 \\
26 \\
76 \\
105 \\
13\end{array}$ & $\begin{array}{l}\text { I } \\
0.68(0.152-3.088) \\
1.02(0.243-4.337) \\
1.02(0.47-4.283) \\
2.16(0.334-14.05)\end{array}$ & $\begin{array}{l}0.622 \\
0.971 \\
0.968 \\
0.418\end{array}$ \\
\hline Marital Status & $\begin{array}{l}\text { Married } \\
\text { Single } \\
\text { Widowed/divorced }\end{array}$ & $\begin{array}{l}40 \\
26 \\
47\end{array}$ & $\begin{array}{l}105 \\
29 \\
92\end{array}$ & $\begin{array}{l}\text { I } \\
1.52(0.68-3.4) \\
2.13(1.17-3.891)\end{array}$ & $\begin{array}{l}0.297 \\
0.013 *\end{array}$ \\
\hline Residence & $\begin{array}{l}\text { Urban } \\
\text { Rural }\end{array}$ & $\begin{array}{l}91 \\
22\end{array}$ & $\begin{array}{l}184 \\
42\end{array}$ & $\begin{array}{l}\text { I } \\
1.06(0.60-1.88)\end{array}$ & 0.844 \\
\hline Alcohol consumption & $\begin{array}{l}\text { Yes } \\
\text { No }\end{array}$ & $\begin{array}{l}28 \\
85\end{array}$ & $\begin{array}{l}25 \\
201\end{array}$ & $\begin{array}{l}2.64(1.45-4.80) \\
I\end{array}$ & $0.001 *$ \\
\hline Smoking & $\begin{array}{l}\text { Yes } \\
\text { No }\end{array}$ & $\begin{array}{l}4 \\
109\end{array}$ & $\begin{array}{l}1 \\
225\end{array}$ & $\begin{array}{l}8.52(0.9 \mid 2-74.7) \\
\text { । }\end{array}$ & 0.06 \\
\hline Khat Chewing & $\begin{array}{l}\text { Yes } \\
\text { No }\end{array}$ & $\begin{array}{l}10 \\
103\end{array}$ & $\begin{array}{l}11 \\
205\end{array}$ & $\begin{array}{l}1.89(0.78-4.6 \mathrm{I}) \\
\mathrm{I}\end{array}$ & 0.157 \\
\hline Drug Adherence & $\begin{array}{l}\text { Good } \\
\text { Fair } \\
\text { Poor }\end{array}$ & $\begin{array}{l}80 \\
17 \\
16\end{array}$ & $\begin{array}{l}207 \\
15 \\
4\end{array}$ & $\begin{array}{l}\text { I } \\
3.52(0.965-12.9) \\
10.3(3.36-31.9)\end{array}$ & $\begin{array}{l}0.057 \\
\mathbf{0 . 0 0 I *}\end{array}$ \\
\hline Isoniazid Prophylaxis & $\begin{array}{l}\text { Yes } \\
\text { No }\end{array}$ & $\begin{array}{l}26 \\
87\end{array}$ & $\begin{array}{l}21 \\
205\end{array}$ & $\begin{array}{l}\text { I } \\
2.91(1.55-5.46)\end{array}$ & $0.001 *$ \\
\hline Cotrimoxazole Prophylaxis & $\begin{array}{l}\text { Yes } \\
\text { No }\end{array}$ & $\begin{array}{l}68 \\
45\end{array}$ & $\begin{array}{l}154 \\
72\end{array}$ & $\begin{array}{l}\text { I } \\
0.70(0.44-1.13)\end{array}$ & 0.147 \\
\hline Recent CD4 Count (cells $/ \mu \mathrm{L})$ & $\begin{array}{l}<200 \\
\geq 200\end{array}$ & $\begin{array}{l}34 \\
79\end{array}$ & $\begin{array}{l}14 \\
212\end{array}$ & $\begin{array}{l}6.517(3.32-12.78) \\
\mathrm{I}\end{array}$ & $0.001 *$ \\
\hline Hgb status (mg/dl) & $\begin{array}{l}<10 \\
\geq 10\end{array}$ & $\begin{array}{l}16 \\
97\end{array}$ & $\begin{array}{l}3 \\
223\end{array}$ & $\begin{array}{l}12.26(3.49-43.0) \\
1\end{array}$ & $0.001 *$ \\
\hline Recent Body mass index & $\begin{array}{l}<18.5 \\
\geq 18.5\end{array}$ & $\begin{array}{l}50 \\
63\end{array}$ & $\begin{array}{l}25 \\
201\end{array}$ & $\begin{array}{l}6.38(3.655-11.14) \\
1\end{array}$ & $0.001 *$ \\
\hline Prev history of Ols & $\begin{array}{l}\text { Yes } \\
\text { No }\end{array}$ & $\begin{array}{l}67 \\
46\end{array}$ & $\begin{array}{l}56 \\
170\end{array}$ & $\begin{array}{l}4.42(2.73 \mid-7.15) \\
\text { I }\end{array}$ & $0.001 *$ \\
\hline History of Ols in Household & $\begin{array}{l}\text { Yes } \\
\text { No }\end{array}$ & $\begin{array}{l}6 \\
107\end{array}$ & $\begin{array}{l}3 \\
223\end{array}$ & $\begin{array}{l}4.16(1.023-16.9) \\
1\end{array}$ & $0.046 *$ \\
\hline
\end{tabular}

Note: *Statistically significant on bivariate analysis p-value less than 0.05

Abbreviations: COR, crude odds ratio; CT, confidence interval; I, reference.

developing opportunistic infections compared to nonalcoholics that is in agreement with previous crosssectional studies done in Ethiopia. ${ }^{18,20}$ It might be explained by alcoholics tend to have other behavioral factors that can result in skipping of drugs that further affect the adherence to ART medications which will, in turn, hinder immunity against opportunistic infections. Additionally, more alcohol consumption also might contribute to have higher HIV viral load thereby suppresses immunity. $^{23}$ 
Table 5 Summary of Multivariate Analysis of Associated Factors with Opportunistic Infections in HIV Patients on HAART, Debre Berhan, Ethiopia, 2020

\begin{tabular}{|c|c|c|c|c|c|}
\hline Variable & & Cases & Control & COR $(95 \% \mathrm{Cl})$ & AOR $(95 \% \mathrm{Cl})$ \\
\hline Sex & $\begin{array}{l}\text { Male } \\
\text { Female }\end{array}$ & $\begin{array}{l}41 \\
72\end{array}$ & $\begin{array}{l}100 \\
126\end{array}$ & $\begin{array}{l}\text { I } \\
0.72(0.45 \mid-1.142)\end{array}$ & $2(0.937-4.27)$ \\
\hline Marital Status & $\begin{array}{l}\text { Married } \\
\text { Single } \\
\text { Widowed/divorced }\end{array}$ & $\begin{array}{l}40 \\
26 \\
47\end{array}$ & $\begin{array}{l}105 \\
29 \\
92\end{array}$ & $\begin{array}{l}\text { I } \\
1.52(0.68-3.4) \\
2.13(1.17-3.891)\end{array}$ & $\begin{array}{l}0.57(0.20-1.62) \\
0.95(0.342-2.64)\end{array}$ \\
\hline Alcohol consumption & $\begin{array}{l}\text { Yes } \\
\text { No }\end{array}$ & $\begin{array}{l}28 \\
85\end{array}$ & $\begin{array}{l}25 \\
201\end{array}$ & $\begin{array}{l}2.64(1.45-4.80) \\
1\end{array}$ & $3.12(1.07-9.06) *$ \\
\hline Smoking & $\begin{array}{l}\text { Yes } \\
\text { No }\end{array}$ & $\begin{array}{l}4 \\
109\end{array}$ & $\begin{array}{l}1 \\
225\end{array}$ & $\begin{array}{l}8.52(0.912-74.7) \\
1\end{array}$ & $1.63(0.05-5.1)$ \\
\hline Drug Adherence & $\begin{array}{l}\text { Good } \\
\text { Fair } \\
\text { Poor }\end{array}$ & $\begin{array}{l}80 \\
17 \\
16\end{array}$ & $\begin{array}{l}207 \\
15 \\
4\end{array}$ & $\begin{array}{l}\text { I } \\
10.3(3.36-31.9) \\
3.52(0.965-12.9)\end{array}$ & $\begin{array}{l}\text { I.I35 (0.23-5.52) } \\
1.08(0.16-6.99)\end{array}$ \\
\hline Isoniazid Prophylaxis & $\begin{array}{l}\text { Yes } \\
\text { No }\end{array}$ & $\begin{array}{l}26 \\
87\end{array}$ & $\begin{array}{l}21 \\
205\end{array}$ & $\begin{array}{l}\text { I } \\
2.91(1.55-5.46)\end{array}$ & $0.87(0.323-2.35)$ \\
\hline Cotrimoxazole Prophylaxis & $\begin{array}{l}\text { Yes } \\
\text { No }\end{array}$ & $\begin{array}{l}68 \\
45\end{array}$ & $\begin{array}{l}154 \\
72\end{array}$ & $\begin{array}{l}\text { I } \\
0.70(0.44-1.13)\end{array}$ & $1.593(0.77-3.26)$ \\
\hline 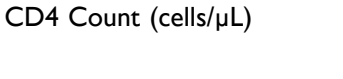 & $\begin{array}{l}<200 \\
\geq 200\end{array}$ & $\begin{array}{l}34 \\
79\end{array}$ & $\begin{array}{l}14 \\
212\end{array}$ & $\begin{array}{l}6.517(3.32-12.78) \\
1\end{array}$ & I.3I (0.42-4.0) \\
\hline Hgb status (mg/dl) & $\begin{array}{l}<10 \\
\geq 10\end{array}$ & $\begin{array}{l}16 \\
97\end{array}$ & $\begin{array}{l}3 \\
223\end{array}$ & $\begin{array}{l}12.26(3.49-43.0) \\
1\end{array}$ & $1.66(0.22-12.5)$ \\
\hline Body mass index & $\begin{array}{l}<18.5 \\
\geq 18.5\end{array}$ & $\begin{array}{l}50 \\
63\end{array}$ & $\begin{array}{l}25 \\
201\end{array}$ & $\begin{array}{l}6.38(3.655-11.14) \\
I\end{array}$ & $3.36(1.49-7.55) *$ \\
\hline Prev history of Ols & $\begin{array}{l}\text { Yes } \\
\text { No }\end{array}$ & $\begin{array}{l}67 \\
46\end{array}$ & $\begin{array}{l}56 \\
170\end{array}$ & $\begin{array}{l}4.42(2.731-7.15) \\
1\end{array}$ & $2.96(1.5 \mathrm{I}-5.8)^{* * *}$ \\
\hline History of Ols in Household & $\begin{array}{l}\text { Yes } \\
\text { No }\end{array}$ & $\begin{array}{l}6 \\
107\end{array}$ & $\begin{array}{l}3 \\
223\end{array}$ & $\begin{array}{l}4.16(1.023-16.9) \\
1\end{array}$ & $0.99(0.11-8.3)$ \\
\hline
\end{tabular}

Note: *Statistically significant on multivariate analysis $\mathrm{p}$-value less than 0.05 ; **statistically significant on multivariate analysis $\mathrm{p}$-value less than $0.00 \mathrm{I}$.

Abbreviations: AOR, adjusted odds ratio; $\mathrm{COR}$ crude odds ratio; $\mathrm{Cl}$, confidence interval; $\mathrm{HH}$, household; Ol, opportunistic infection; I, reference.

Patients having a hemoglobin level of $<10 \mathrm{mg} / \mathrm{dl}$ have a higher risk of developing OIs than those patients having a hemoglobin level $>12.5 \mathrm{mg} / \mathrm{dl}$. This study is similar to another study. ${ }^{17}$ But, in contrast with other studies done in Dawro, Addis Ababa, Debre Markos, and North-western Ethiopia. $^{20-22,24}$

Malnutrition is also an independent factor for developing opportunistic infections. Low body mass index is strongly associated with active OIs where the odds of developing an opportunistic infection in malnourished patients are 3.3 times higher than well-nourished individuals, which is similar to other reports from Addis Ababa, Northeast Ethiopia and Eastern Ethiopia. ${ }^{17,20,22,24}$ This could be because of the opportunistic infection could lead to malnutrition and anemia through a loss of appetite and pain during swallowing, and increased metabolic rate and malabsorption. Conversely, malnutrition can exacerbate immune deficiency and cause the development of opportunistic infections in patients with HIV.

The previous history of opportunistic infection was found to be independently associated with almost a 3 times higher rate of occurrence of opportunistic infections. This could be due to an already suppressed immune system that has poor resistance to opportunistic infections. Opportunistic infections can also decrease the immunity against other opportunistic infections and predispose a person to multiple illnesses at a time. 
The case-control study design of this work might produce possible limitations in that it could only show associations. The temporal relationships and causations are not able to infer by a case-control study design. Moreover, time on HAART and HIV diagnosis date is limited for this study.

\section{Conclusion}

The study identified alcohol consumption, lower BMI, and previous history of OIs as predictors of higher opportunistic infection among HIV-positive people who are on HAART. Behavioral factors like poor drug adherence are also potential risk factors for opportunistic infections. The poor clinical and biochemical status were attributed for independent predictors of the existence of opportunistic infections.

\section{Abbreviations}

AIDS, Acquired Immune Deficiency Syndrome; AOR, Adjusted Odds Ratio; ART, Anti-Retroviral Treatment; ARV, Anti-Retrovirus; BMI, Body Mass Index; CD4, Cluster of Differentiation 4; CI, Confidence Interval; CNS, Central Nervous System; COR, Crude Odds Ratio; DBRH, Debre Berhan Referral Hospital; HAART, Highly Active Anti-Retroviral Treatment; HIV, Human Immune Deficiency Virus; OI, Opportunistic Infections; OPD, Out Patient Department; PCP, Pneumocystis carinii pneumonia; SPSS, statistical package for social science; TB, Tuberculosis; WHO, World Health Organization.

\section{Ethics Approval and Consent to Participate}

Ethical approval was obtained from the College of Health Science Institutional Review Board, Debre Berhan University. Full information was given to participants on the purpose and significance of the study. The informed and written consent was then obtained from all participants and it was conducted following the declaration of Helsinki. ${ }^{25}$ Parental informed consent was obtained for the participants under the age of 18 years old.

\section{Acknowledgment}

The authors express thanks to all ART clinic staff of DBRH and study participants who were voluntarily involved in this study.

\section{Author Contributions}

All authors made substantial contributions to conception and design, acquisition of data, or analysis and interpretation of data; took part in drafting the article or revising it critically for important intellectual content; agreed to submit to the current journal; gave final approval of the version to be published; and agree to be accountable for all aspects of the work.

\section{Disclosure}

The authors declared no conflicts of interest in this work.

\section{References}

1. Kasper F. Harrison's Principles of Internal Medicine. 19th ed. New York: The McGraw-Hill Companies, Inc.; 2015.

2. Guidelines for the prevention and treatment of opportunistic infections in HIV-infected adults and adolescents: recommendations from the Centers for Disease Control and Prevention, the National Institutes of Health, and the HIV Medicine Association of the. Available from: http://aidsinfo.nih.gov/contentfiles/lvguidelines/ adult_oi.pdf. Accessed March 23, 2021.

3. Ethiopian Public Health Institute and ICAP at Columbia University, Ethiopia Population-Based HIV Impact Assessment (EPHIA) 2017-2018. Summary Sheet: Preliminary Findings; April, 2018:4-7.

4. Urgessa F, Ararsa A, Ataro Z. Prevalence and associated risk factors of opportunistic infections among anti-retro viral treatment naive HIV/AIDS infected patients. J AIDS Clin Res. 2018;09(03). doi:10.4172/2155-6113.1000763

5. Ethiopian Public Health Institute. HIV related estimates and projections for Ethiopia. Ethiopian Public Health Institute; March, 2017.

6. Moore RD, Chaisson RE. Natural history of opportunistic disease in an HIV-infected urban clinical cohort (Reprinted from Annals of Internal Medicine, vol 124, pg 633-642, 1996). Formulary. 1997;32:S32-42. doi:10.7326/0003-4819-124-7-199604010-00003

7. Benson CA, Kaplan JE, Masur H, Pau A, Holmes KK. Treating opportunistic infections among HIV-infected adults and adolescents: recommendations from $\mathrm{CDC}$, the National Institutes of Health, and the HIV Medicine Association/Infectious Diseases Society of America. Clin Infect Dis. 2005;40(Supplement_3):S131-235.

8. CDC - Centers for Disease Control and Prevention. Morbidity and Mortality Weekly Report - guidelines for the prevention and treatment of opportunistic infections among HIV-exposed and HIVinfected children; 2009:58.

9. Ethiopia Federal HIV/AIDS Prevention and Control Office. Guidelines for management of opportunistic infections and anti-retroviral treatment in adolescents and adults in Ethiopia, March 2008; March, 2008:1-109.

10. Federal Ministry of Health. National guidelines for comprehensive HIV prevention, care and treatment; 2017:44-46.

11. Federal HIV/AIDS Prevention and Control Office. HIV prevention in Ethiopia: National Road Map; November, 2018:1-43.

12. Benson CA, Kaplan JE, Masur H, Pau A, Holmes KK. Treating opportunistic infections among HIV-exposed and infected children: recommendations from $\mathrm{CDC}$, the National Institutes of Health, and the Infectious Diseases Society of America. MMWR Mob Mortal Weekly Recommit Rep. 2005;53(RR-15):1-112.

13. Kaplan JE, Hanson D, Dworkin MS, et al. Epidemiology of human immunodeficiency virus-associated opportunistic infections in the United States in the Era of highly active antiretroviral therapy. Clin Infect Dis. 2000;30(s1):S5-14. doi:10.1086/313843

14. Hamza OJM, Matee MIN, Simon ENM, et al. Oral manifestations of HIV infection in children and adults receiving highly active anti-retroviral therapy [HAART] in Dar es Salaam, Tanzania. BMC Oral Health. 2006;6(1):1-9. doi:10.1186/14726831-6-12 
15. Khongkunthian $\mathrm{P}$, Grote $\mathrm{M}$, Isaratanan W, Piyaworawong $\mathrm{S}$, Reichart PA. Oral manifestations in $45 \mathrm{HIV}$-positive children from Northern Thailand. J Oral Pathol Med. 2001;30(9):549-552. doi:10.1034/j.1600-0714.2001.300907.x

16. Gona P, Williams PL, Chernoff MC, et al. Incidence of opportunistic and other infections in HIV-infected children in the HAART era. J Am Med Assoc. 2006;296(3):292-300. doi:10.1001/jama.296.3.292

17. Mitiku H, Weldegebreal F, Teklemariam Z. Magnitude of opportunistic infections and associated factors in HIV-infected adults on antiretroviral therapy in eastern ethiopia. HIV/AIDS Res Palliat Care. 2015;7:137-144. doi:10.2147/HIV.S79545

18. Mitiku AA, Dessie ZG, Muluneh EK, Workie DL. Prevalence and associated factors of TB/HIV co-infection among HIV Infected patients in Amhara region, Ethiopia. Afri Health Sci. 2016;16 (2):588-595. doi:10.4314/ahs.v16i2.29

19. Damtie D, Yismaw G, Woldeyohannes D, Anagaw B. Common opportunistic infections and their CD4 cell correlates among HIV-infected patients attending at antiretroviral therapy clinic of Gondar University Hospital, Northwest Ethiopia. BMC Res Notes. 2013;6(1). doi:10.1186/1756-0500-6-534

20. Solomon FB, Angore BN, Koyra HC, Tufa EG, Berheto TM, Admasu M. Spectrum of opportunistic infections and associated factors among people living with HIV/AIDS in the era of highly active anti-retroviral treatment in Dawro Zone hospital: a retrospective study. BMC Res Notes. 2018;11(1):1-7. doi:10.1186/ s13104-018-3707-9
21. Kibret KT, Yalew AW, Belaineh BG, Asres MM. Determinant factors associated with occurrence of tuberculosis among adult people living with HIV after antiretroviral treatment initiation in Addis Ababa, Ethiopia: a Case Control Study. PLoS One. 2013;8(5):23-27. doi:10.1371/journal.pone.0064488

22. Mohammed T, Taha M, Deribew A, Tessema F, Assegid S, Colebunders R. Risk factors of active tuberculosis in people living with HIV/AIDS in Southwest Ethiopia. Ethiop J Health Sci. 2009;21 (2):131-139. doi:10.4314/ejhs.v21i2.69053

23. Wu ES, Metzger DS, Lynch KG, et al. Association between alcohol use and HIV viral load. J Acquir Immune Defic Syndr. 1999;56.5 (2011):e129. doi:10.1097/QAI.0b013e31820dc1c8

24. Moges NA, Kassa GM. Prevalence of opportunistic infections and associated factors among HIV positive patients taking anti-retroviral therapy in Debre Markos referral hospital, northwest Ethiopia. J AIDS Clin Res. 2014;5(5). doi:10.4172/2155-6113.1000301

25. World Medical Association. World Medical Association declaration of Helsinki. Ethical principles for medical research involving human subjects. Bull World Health Organ. 2001;79(4):373-374. World Health Organization.
HIV/AIDS - Research and Palliative Care

\section{Publish your work in this journal}

HIV/AIDS - Research and Palliative Care is an international, peerreviewed open-access journal focusing on advances in research in HIV, its clinical progression and management options including antiviral treatment, palliative care and public healthcare policies to
Dovepress

control viral spread. The manuscript management system is completely online and includes a very quick and fair peer-review system, which is all easy to use. Visit http://www.dovepress.com/testimonials.php to read real quotes from published authors. 